\title{
Role of Stress Management in increasing Employee Productivity at workplace
}

\author{
Sulaiman.N, Allah Baksh.S
}

\begin{abstract}
Now-a-days in every IT/ITES Sector employee are facing so much of work pressure which makes them have a lack of work-life balance. Being stressed affects both employer and employee. Employee's personal life, as well as professional life, will affect and from the point of organization, productivity will be decreased. The only way to increase productivity is to make employees stress free about their work. Having a good stress management techniques helps in increasing employee productivity which influences in organizations reputation. The major objective is to measure the impact of Job Stress on Employee's Productivity and to identify the role of stress management in increasing employee productivity. The research hypothesis was evaluated using statistical tools such as Factor Analysis and Regression. 320 respondents were analyzed using a Convenience sampling method. The findings revealed that there is an impact of job stress on employee's productivity and some of the factors increases employee's productivity is Psychological Support Factor, Comfortability Factor, Efficiency Factor, Technical Factor, and Clarity Factor. Role of Stress Management is to provide good support for both psychological and Physical support. It is clear that stress management helps in increasing the productivity of the employee.
\end{abstract}

Index Terms: Employee productivity, Factor Analysis, regression. Stress Management

\section{INTRODUCTION}

Stress has been related to each human life and is there to remain for all times to return. Right from birth, each individual is doubtless exposed to varied trying things. However, stress isn't perpetually dangerous. Some stress necessary to encourage and stimulate us. Hence, the stress of sure level is incredibly useful. Stress could be a reality of each human life and largely old by IT professionals. It's become an excellent matter of concern for the staff of IT organizations. The employees working within the IT Sector face a lot of stress as a result of they need to update their data endlessly. Updating themselves makes them more stressed. Bindurani (2014) agrees that social support helps employees to reduce their stress level who are all working in the IT Sector. Reducing the stress of an employee plays a major role in the organization's development. Every IT employees face so much of problem because of stress. No organization can claim stress-free work. Providing employees too much of works and improper job role makes employees feel so stressed. Busharabano (2012) states that providing different stress management techniques helps employees in reducing their stress which reflects in both employee's life and employer's reputation. Every IT Sector employees are expecting the best stress management technique to make them feel less tensed and work without tension. Claudia neptina (2013) explains that Job Stress has an impact on productivity of employees. Job Stress and Employee's Productivity related to each other. Once employees feel stressed, it automatically implies in their productivity which spoils the reputation of an organization. The major role of Stress Management helps in increasing employee's productivity.

\section{REVIEW OF LITERATURE}

Essien blessing Stephen (2014) stated that occupational stress reduced because of adapting some strategies. Data were collected from commercial bank employees in Akwalbom State South, South Nigeria. Analysis reveals that adopting the best strategy to reduce stress management helps employee's to be more productive.

Eunice modupe Hassan (2009) revealed that job stress has a relationship with job performance. Data were collected from the Banking Sector in Pakistan. T-test, statistical tools were used to test the data. Study reveals that when employees having more stress towards their job won't produce a good result. Poor performance will be the result of a stressful job and stressed employees.

Radha (2014) studied about the occupational stress and job performance among bank employees in trivarur district of Tamilnadu. Collected data were analyzed using the chi-square test. From the analysis, it was found that occupational stress has an association with job performance.

Helen o sinowo (2009) analysed the relationship of poor job satisfaction and psychological well being of employees. Data were collected from employees of the Nigerian Banking Sector. T-Test was used to analysis the data. Result reveals that when an employee is not satisfied with their job then automatically it will affect psychological well being of employees.

Jyoti Sharma (2013) investigated the role of stress management in employee productivity. Respondents are front line, bank employees. Study reveals that providing proper stress management helps in improving employee's productivity.

Khurramzafar (2012) conducted a comparative analysis to know the stress level of private and public banking employees. T-test analysis was used to analysis the data. From the analysis, it was found that both private and public banking employees are facing the same stress level in their job. 


\section{RESEARCH METHODOLOGY}

\section{A. Research Design}

The descriptiveresearch design was used in this study with particular reference to Coimbatore. The sample size was 320 employees working in different IT/ITES Sector in Coimbatore. Convenience sampling technique was used. Structured questionnaire were used to collect the data.

\section{B. Objectives of the Study}

- To measure the impact of Job Stress on Employee's Productivity.

- To identify the role of Stress Management in increasing Employee Productivity.

-

\section{Statistical Tools}

\begin{tabular}{|l|l|l|}
\hline S.no & \multicolumn{1}{|c|}{ Description of objectives } & \multicolumn{1}{|c|}{$\begin{array}{c}\text { Statistical } \\
\text { tools for } \\
\text { analysis }\end{array}$} \\
\hline 1 & $\begin{array}{l}\text { To measure the impact of Job } \\
\text { Stress on Employee's } \\
\text { Productivity. }\end{array}$ & Regression \\
\hline 2 & $\begin{array}{l}\text { To identify the role of Stress } \\
\text { Management in increasing } \\
\text { Employee Productivity. }\end{array}$ & $\begin{array}{l}\text { Factor } \\
\text { Analysis }\end{array}$ \\
\hline
\end{tabular}

\section{DATA ANALYSIS}

\section{A. Impact of Job Stress on Employee's Productivity}

Table 1: Model Summary

\begin{tabular}{|c|c|c|c|c|}
\hline Model & R & Square & $\begin{array}{c}\text { Adjusted R } \\
\text { Square }\end{array}$ & $\begin{array}{c}\text { Std. The error } \\
\text { of the Estimate }\end{array}$ \\
\hline 1 & $.954(\mathrm{a})$ & .910 & .910 & .178 \\
\hline
\end{tabular}

From Table I, R value of 0.954 , indicates a good level of prediction. The $R^{2}$ value is 0.910 that Job Stress explain $91.0 \%$ of the variability of the dependent variable (Employee's Productivity).

Table 2: ANOVA $^{\mathbf{b}}$

\begin{tabular}{|cc|c|c|c|c|c|}
\hline & Model & $\begin{array}{c}\text { Sum of } \\
\text { Squares }\end{array}$ & df & $\begin{array}{c}\text { Mean } \\
\text { Square }\end{array}$ & F & Sig. \\
\hline 1 & Regression & 96.661 & 1 & 96.661 & 56.222 & $.000^{\mathrm{a}}$ \\
& $\begin{array}{l}\text { Residual } \\
\quad \text { Total }\end{array}$ & 9.539 & 318 & .030 & & \\
& 106.200 & 319 & & & \\
\hline
\end{tabular}

a. Predictors: (Constant), Job Stress

b. Dependent Variable: Employee's Productivity

Table II, explains that the Employee's Productivity statistically significantly predict the Job Stress, $F(1,318)=$ $56.222, p<.000$. It's clear that regression model is very well fit.
Table 3

\begin{tabular}{|l|c|c|c|c|c|}
\hline \multirow{2}{*}{ Model } & \multicolumn{2}{|c|}{$\begin{array}{c}\text { Unstandardized } \\
\text { Coefficients }\end{array}$} & $\begin{array}{c}\text { Standardized } \\
\text { Coefficients }\end{array}$ & & \multirow{2}{*}{ Sig. } \\
\cline { 2 - 4 } & $\mathrm{B}$ & Std. Error & Beta & $\mathbf{t}$ & \multicolumn{1}{|c|}{. } \\
\hline $1 \quad$ (Constant) & .142 & .079 & & 1.811 & .031 \\
Job Stress & .962 & .017 & .954 & 56.766 & .000 \\
\hline
\end{tabular}

a. Dependent Variable: Employee's Productivity

Table3 shows that there is an impact of job stress on employee's productivity.

\section{B. Role of Stress Management in increasing Employee Productivity}

Table 4: KMO and Bartlett's Test

\begin{tabular}{|l|l|l|}
\hline $\begin{array}{l}\text { Kaiser-Meyer-Olkin } \\
\text { Measure of Sampling } \\
\text { Adequacy }\end{array}$ & Approx. Chi-Square \\
Sphertlett's Test of & 8956.217 \\
\hline & df & 496 \\
\hline & Sig. & 0 \\
\hline
\end{tabular}

Based on table 4, it is identified that internal coherence of the data was appropriate which is more than the base limit $(\mathrm{KMO}=0.768)$ while Bartlett's statistic was significant at the 0.000 level (8956.217). The result values of communalities extraction values of all the 30 variables were more than 0.4 which is the loading factor of criterion level.

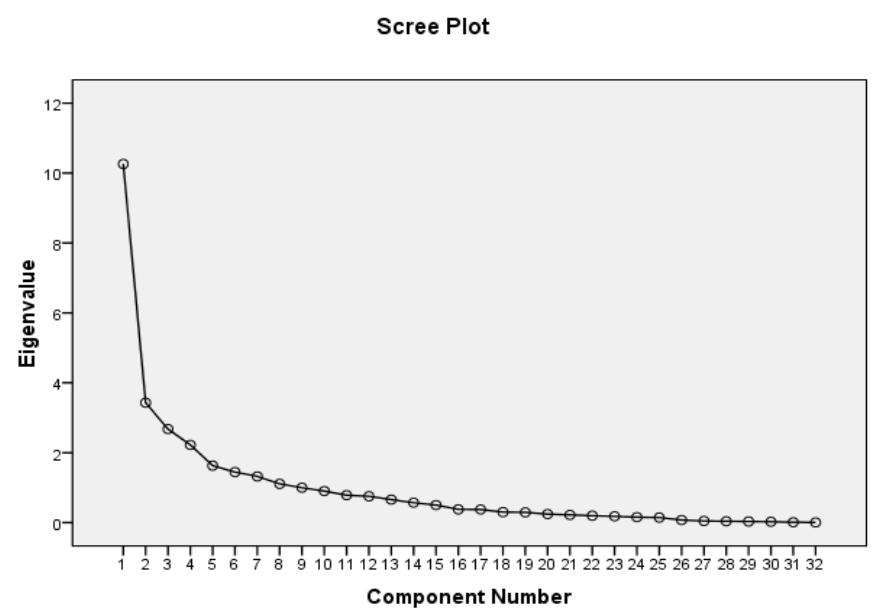


Table 5

\begin{tabular}{|c|c|c|c|c|c|}
\hline & & & Compone & & \\
\hline & 1 & 2 & 3 & 4 & 5 \\
\hline & $\begin{array}{l}\text { Psycho } \\
\text { logical } \\
\text { Factor }\end{array}$ & $\begin{array}{c}\text { Comfo } \\
\text { rtabili } \\
\text { ty } \\
\text { Factor }\end{array}$ & $\begin{array}{l}\text { Efficie } \\
\text { ncy } \\
\text { Factor }\end{array}$ & $\begin{array}{l}\text { Techni } \\
\text { cal } \\
\text { Factor }\end{array}$ & $\begin{array}{l}\text { Clarit } \\
\mathbf{y} \\
\text { Factor }\end{array}$ \\
\hline Counseling & 0.666 & & & & \\
\hline Meditation & 0.504 & & & & \\
\hline Relaxation & 0.623 & & & & \\
\hline Social Support & 0.521 & & & & \\
\hline $\begin{array}{l}\text { Time } \\
\text { Management } \\
\& \text { Goal Setting }\end{array}$ & 0.854 & & & & \\
\hline $\begin{array}{l}\text { Physical } \\
\text { Exercise }\end{array}$ & 0.413 & & & & \\
\hline $\begin{array}{l}\text { Employee } \\
\text { Grievance } \\
\text { Handling }\end{array}$ & 0.424 & & & & \\
\hline $\begin{array}{l}\text { Good } \\
\text { Relationship } \\
\text { at Works }\end{array}$ & 0.662 & & & & \\
\hline $\begin{array}{l}\text { Retirement } \\
\text { Packages }\end{array}$ & & 0.574 & & & \\
\hline $\begin{array}{l}\text { Fringe } \\
\text { Benefits } \\
\end{array}$ & & 0.472 & & & \\
\hline Insurance & & 0.543 & & & \\
\hline Motivation & & 0.628 & & & \\
\hline $\begin{array}{l}\text { Performance } \\
\text { Appraisal }\end{array}$ & & 0.537 & & & \\
\hline $\begin{array}{l}\text { Reimburseme } \\
\text { nt \& Benefits }\end{array}$ & & 0.664 & & & \\
\hline Job Rotation & & & 0.648 & & \\
\hline $\begin{array}{l}\text { Job } \\
\text { enrichments }\end{array}$ & & & 0.693 & & \\
\hline Job Clarity & & & 0.648 & & \\
\hline $\begin{array}{l}\text { Proper Job } \\
\text { Role }\end{array}$ & & & 0.497 & & \\
\hline $\begin{array}{l}\text { Work in } \\
\text { Group }\end{array}$ & & & 0.588 & & \\
\hline $\begin{array}{l}\text { Characteristic } \\
\mathrm{s} \text { of the Job }\end{array}$ & & & 0.666 & & \\
\hline Promotions & & & & 0.748 & \\
\hline Training & & & & 0.757 & \\
\hline $\begin{array}{l}\text { Communicati } \\
\text { on Process }\end{array}$ & & & & 0.637 & \\
\hline Develop Team & & & & 0.566 & \\
\hline $\begin{array}{l}\text { Managing } \\
\text { workplace } \\
\text { conflicts }\end{array}$ & & & & 0.793 & \\
\hline $\begin{array}{l}\text { Flexible work } \\
\text { arrangements }\end{array}$ & & & & 0.667 & \\
\hline $\begin{array}{l}\text { Healthy } \\
\text { Lifestyle } \\
\end{array}$ & & & & & 0.625 \\
\hline $\begin{array}{l}\text { Wellness } \\
\text { Programs }\end{array}$ & & & & & 0.651 \\
\hline $\begin{array}{l}\text { Company } \\
\text { Culture }\end{array}$ & & & & & 0.593 \\
\hline $\begin{array}{l}\text { Work } \\
\text { Behaviour }\end{array}$ & & & & & 0.676 \\
\hline
\end{tabular}

Table 5 explains the five different factor in which the role of stress management in increasing employee productivity. Five different factors are Comfortability factor, Psychological Factor, Efficiency Factor, Technical Factor, and Clarity Factor.

\section{CONCLUSION}

Every IT/ITES Sector employee's face stress in the workplace. In-order to make employees stress free, employers should adopt stress management. Role of stress management helps in increasing employee productivity. Study reveals that Job Stress has an influence on employee's productivity. Employee's productivity totally depends on job stress which they are facing. When stress management introduced in employee's job, automatically employees feel free from their stress. Role of stress management normally increases employee productivity. Providing proper stress management helps employees in providing a good improvement in an individual. Comfortability factor, Psychological Factor, Efficiency Factor, Technical Factor, and Clarity Factor makes a change in employee's productivity and reduce the stress.

\section{REFERENCES}

[1] Susan Rhodes and Richard Steers, "A Systematic Approach to Diagnosing Employee Absenteeism", Employee Relations, Vol. 3 Issue: 2, 1981, pp.17-22, https://doi.org/ 10.1108/eb054966,

[2] Madeline Weiss, MIS March, "Work Stress and social support, Effects of Work Stress and Social Support on Information Systems", 1983.

[3] José Humberto Ablanedo-Rosas, Randall C. Blevins, HongmanGao, Wen-Yuan Teng, Joann White, The impact of occupational stress on academic and administrative Staff, and on students: an empirical case analysis", Journal of Higher Education Policy and Management, Vol. 33, No. 5, 2011, pp. 553-564

[4] AyazulHaq, "Occupational stress and burn out in pakistans banking sector", African journal of business management, 5 (3), 2011, pp.810-817.

[5] Sharmila, A, "A study on employees management in selected private banks in Salem", Elixir international journal, 42, 2012 , pp.6555-6558.

[6] Silva J. L., Navarro V. L., "Work organization and the health of bank employees", Rev. Latino Am. Enfermagem. 20, 2012, pp.226-234. 10.1590/S0104-11692012000200003.

[7] Asfaq Ahmed, "Effect of job stress on employees job performance a study on the banking sector of Pakistan", IOSR journal of business and management, 11, 2013, pp. 61-68.

[8] Ambika Ponnampalam, "A study on the effect of stress on the performance of employees in the commercial bank of ceylon in the eastern province", European journal of business management, 1 (27), 2013, pp.87-95

[9] Angweling, "A study on role stress and job satisfaction among bank employees in kotak in a balusabah", International journal of research in management and business studies, Volume 1 Issue 2, 2014 pp.19-23. 